was surprising that only one mitotic cell coming from the thymic graft could be identified in the spleen although good preparations were obtained from all seven animals and over 900 mitoses were examined. Conceivably this could have been due to selection of mitoses from erythropoietic and granulopoietic regions of immature spleens. Histological examination of portions of the spleens, however, showed that they were composed largely of lymphoid tissue. The frequent presence of donor cells in the lymph-nodes and their virtual absence from the spleen suggests a functional distinction of some kind between the lymphoid tissue at the two distinct anatomical sites. It is conceivable that this distinction may be associated with a capacity on the part of the thymus to release cells of two kinds, one destined primarily for lymph-nodes and the other primarily for spleen. Our failure to detect the latter class may have been associated with a selective loss of cells before the graft becomes vascularised. Extensive cellular destruction is known to occur when thymuses from older animals (not newborn) are grafted into adult hosts. ${ }^{5-7}$

No donor cells were found among the 426 bone-marrow cells examined, but this is not unexpected.

These findings are consistent with the current hypothesis that the thymus is directly concerned in the dispersal of potentially immunocompetent cells (or their progenitors) to lymphoid tissue. ${ }^{89} \mathrm{We}$, following Loutit ${ }^{10}$ and Miller, ${ }^{1}$ have considered the possibility that in the discharge of this function the thymus may act as an "instructional centre" for cells that originate elsewhere ( ? bone-marrow) rather than as their primary source. Moreover Miller's results and our own demonstrate that the host animal possesses cells able to infiltrate and largely repopulate the grafted thymus. The question is therefore raised whether eventually these cells also would migrate selectively to lymphoid tissue. In principle this question could be answered by transplanting the original thymic graft into a (CBA $\times$ CBA-T6T6) $\mathrm{F}_{1}$ secondary host. The cells of the new host would be marked by a single short chromosome and would be distinguishable from the cells of both original donor and primary host. This experiment is being attempted.

Since this letter was originally drafted, Dr. Miller has informed us that he has also succeeded in demonstrating the presence of cells from thymic grafts in lymph-nodes.
Medical Research Council,
Radiobiological Research Unit,
Harwell, Didcot, Berkshire
J. E. Harris
C. E. FORD.

\section{SERUM ENZYMES DURING RECOVERY FROM MALNUTRITION}

SIR,-We were interested in Dr. McClean's article, ${ }^{11}$ but he is attributing to us views which we do not hold. Nowhere did we "imply that that it is in conditions of cells damage and necrosis (our italics) that serum-enzymes are increased". In the publications cited, we gave several instances in vitro and in vivo where increases in serumenzyme activity was unassociated with necrosis. The alternative suggestion-namely, that necrosis is always responsible for a rise in serum-enzyme activity-was considered by us as "less likely" largely on the basis of Zierler's work.

We are glad that Dr. McClean's data offer further support of our suggestion, and we would assure him that his hypothesis is in no way opposed to that held by us and many others. We are encouraged that Dr. McClean is

5. Law, L. W., Miller, J. H. F. nat. Cancer Inst. 1950, 11, 425.

6. Carnes, W. H., Kaplan, H. S., Brown, M. B., Hirsch, B. B. Cancer Res. $1956,16,429$.

7. Metcalf, D., Sparrow, N., Nakamura, K., Ishidate, M. Aust. F. exp. Biol. med.'Sci. 1961, 39, 441 .

8. Auerbach, R. Proc. Nat. Acad. Sci. 1961, 47, 1175.

9. Miller, J. F. A. P Lancet, 1961, ii, 748 .

10. Loutit, J. F. Irradiation of Mice and Men; p. 61. Chicago, 1962

11. Lancet, 1962 , ii, 1294 apparently in a position to attempt to provide experimental proof for these suggestions. Such efforts are needed in an area where the ratio of hypotheses and speculations to evidence is distressingly high.

Section of Gastroenterology,

Department of Internal Medicine, University of Michigan, Ann Arbor, Michigan.

KEITH S. HENLEY

Medizinische Universitaetspoliklinik, Marburg, Germany.

FRIEDRICH W. SCHMIDT

ELLEN SCHMIDT.

\section{TOXOPLASMOSIS AND LYMPHADENITIS}

SIR,-May I comment on the two interesting papers ${ }^{12}$ on febrile lymphadenopathy in toxoplasmosis?

In both these papers deductions were made from clinical and serological evidence as to the date of infection. Both cases had complement-fixation-test titres of $1 / 16$ on initial examination. The dye tests were not significantly different; their titres were $1 / 512$ and $1 / 1024$. In Dr. Watson's paper it was suggested that the patient's infection was four months before the initial serum examination, in Dr. Harrison's case four years previously. It is well known that dye-test antibodies persist in high titres for six months or so. The date of infection is thus very difficult to determine with any accuracy.

In view of the interest shown in this disease, may I suggest that sera are examined early in the disease and again during convalescence, together with biopsy specimens where possible, so that attempts may be made to isolate the organism? As toxoplasmosis is frequently a subclinical infection, it may be necessary to examine repeated samples of serum (say, three months apart) from young normal adults. When rises in antibody titre of at least eightfold occur, detailed clinical and epidemiological inquiries should be instituted. From the evidence of serumantibody surveys, one would expect the attack-rate to be approximately 1\% per year in the age-group 10-30 years. Such an inquiry might provide information on seasonal infection and give a clearer picture of the disease.
Public Health Laboratory Service, Swansea.
D. G. FLECK.

\section{APPEALS TO MENTAL HEALTH REVIEW TRIBUNAL}

SIR,-Sympathy must be felt for Dr. Fleming (Feb. 2) who still had 646 formally detained subnormal patients out of 2400 at the end of the initial period and 49 appeals to the tribunal during the first twelve months, although it is very doubtful whether these figures are typical of the average hospital for the subnormal. It would be relevant and perhaps illuminating to have more detailed statistics from the Ministry of Health.

There can be no doubt, however, that his criticisms of the adverse clinical effects of the tribunal system provoke much thought, unless it is to be reserved only for the occasional case, impossible of resolution by any other means. The fact that, in his two examples, the appeals were made on his advice suggests this is not so.

The Mental Health Review Tribunal crystallises the whole basic dichotomy of the psychiatric hospital-whether it is to be a custodial institution or a therapeutic mechanism geared entirely to the clinical needs of its patients. One wonders whether the difficulties of decision by the " responsible medical officer", as mentioned by Dr. Fleming, would be substantially eased if he knew that he had at his disposal an active rehabilitation programme, a buoyant outpatients system run by his hospital for continuing support, and a close personal integration with the local authority services, and, if so, whether he would feel able to be more liberal in dealing with his patients under informal conditions. I do not know if, in fact, these

1. Harrison, R. J., Broomfield, B. E., Kippax, P. W. Lancet, Feb. 2, 1963. 2. W. 247. atson, G. I. ibid. 1962, ii, 1355. 